\title{
A qualitative exploration of the perspectives of international medical students residing in university hostels amid COVID-19 pandemic lockdown
}

Sitaram Khadka ${ }^{1,2}$, Muhammad Usman ${ }^{3 *}$, Mohammad Saleem ${ }^{2}$, Moshin Ali ${ }^{4}$, Huma Rasheed ${ }^{3}$, Santoshi Giri ${ }^{5}$, Hafiz Asad Saeed ${ }^{6}$, Ravi Prasad Gupta ${ }^{2}$, Yogesh Bajgain ${ }^{2}$, Janak Shahi ${ }^{2}$

${ }^{1}$ Shree Birendra Hospital; Nepalese Army Institute of Health Sciences, Kathmandu, Nepal

${ }^{2}$ Punjab University College of Pharmacy, University of the Punjab, Lahore, Pakistan

${ }^{3}$ Institute of Pharmaceutical Sciences, University of Veterinary and Animal Sciences, Lahore, Pakistan

${ }^{4}$ Faculty of Pharmaceutical Sciences, Government College University, Faisalabad, Pakistan

${ }^{5}$ Nepal Public Health Research and Development Center, Kathmandu, Nepal

${ }^{6}$ Pak Emirates Military Hospital, Rawalpindi, Pakistan

\footnotetext{
*Name: Muhammad Usman

E-mail: usman.ips@uvas.edu.pk

Contact: +92-3334548265

Address: Institute of Pharmaceutical Sciences, University of Veterinary and Animal Sciences, Lahore, Pakistan
} 


\section{ABSTRACT}

Background COVID-19 pandemic has portentously frightened the existence of life all over the world. The lockdown approach was adopted as a containment strategy as the disease itself has manifested severe social, economic, and psychiatric implications.

Objectives To explore the perception and preparedness of international medical students residing in university hostels amid the COVID-19 pandemic lockdown.

Design A semi-structured interview guide was developed in this qualitative study design. All the interviews were audio-taped, transcribed verbatim, and then analyzed for thematic contents by standard content analysis framework.

Setting Interviews were conducted in university hostels in Punjab, Pakistan.

Participants A total of 11 international medical students were interviewed face-to-face through the purposive sampling technique to obtain in-depth individual viewpoints.

Results The thematic content analysis yielded five major themes: Familiarity with COVID-19, Perceptions and attitudes towards COVID-19, Preparedness for safety against COVID-19, Barriers to lifestyle, and Psychological perspectives. A better general perception and preparedness among international medical students regarding COVID-19 was found. Good knowledge regarding the overview of COVID-19; adequate preventive approaches such as social distancing, use of masks, gloves, and sanitizers; and compliance with the lockdown measures were reported by the respondents. The pertinent issue raised by the respondents is the disturbance in normal routine due to distortion in social life and isolation that may cause psychological stress. 
Conclusions The findings from this study lighten the people's perspectives that help the government to prepare public health strategies based on population-focused approaches. The present study demonstrates the respondents' opinion on COVID-19 management by personal hygiene, social distancing, and complying with the lockdown measures. Furthermore, it demands that timely and evidence-based teaching-learning techniques should be adopted for students' engagement which ensures mental health and self-motivation as well. Therefore, they can utilize their time productively which could have a long-term effect on their careers and healthcare services.

Keywords: Universities, COVID-19, Students, Medical, Pakistan, Life $\quad$ Style, Stress, Psychological 
medRxiv preprint doi: https://doi.org/10.1101/2021.08.02.21261480; this version posted August 5, 2021. The copyright holder for this preprint (which was not certified by peer review) is the author/funder, who has granted medRxiv a license to display the preprint in perpetuity.

All rights reserved. No reuse allowed without permission.

\section{INTRODUCTION}

On 11 March 2020, the World Health Organization (WHO) declared COVID-19 as a global pandemic ever since it has manifested itself as serious public health and developmental challenge that has viciously affected all the domains of quality of life including health, socio-economic, and education. ${ }^{1}$ Till date, it has affected more than one hundred and ninety-five million people with more than four million deaths around the world. ${ }^{2}$ Even after the passage of a year, the uncertainty of the approved therapeutic agent exists for the therapy of COVID-19. However vaccines are now being available recently for people aged older than 12 years, it still takes more than a year to fully cover all the countries around the globe. ${ }^{3,4}$ In such adverse scenarios, repurposing of prior available medications and supportive treatment is being practiced as a treatment option considering all the pros and cons. ${ }^{5}$ Various preventive approaches such as lockdown, social distancing, adequate hygiene and sanitation, and wearing masks for breaking the chain of transmission are the mainstay of patient care as of now. ${ }^{6}$

Though the international students are not enlisted in a high-risk group, they are severely affected during the lockdown period socially and economically given their immigration status. ${ }^{7}$ International students, particularly from lower and middle-income countries (LMICs) are already facing challenging circumstances including financial crunches. Lockdown measures add to their plight and potentially lead them into social and psychological stress. ${ }^{7}$

Pakistan takes students from different parts of the world for higher education in the medical and non-medical fields. Most of the international students stay in hostels provided by their universities. Amid the COVID-19 pandemic, they are confined to the hostels. Disruption in education, travel restriction, closure of the mess, isolation, closed border amid lockdown have impaired their daily activities. Fear of infection, anxiety, hoax calls, cyberbullying, and financial 
crisis may cause a substantial impact on mental health amid COVID-19 preventive activities. ${ }^{8-10}$ Such stress-associated disorders may lead to suicidal behavior as well. ${ }^{11}$ In this scenario, assessing the stress level of international students who are confined in hostels amid the COVID19 pandemic and understanding their perception and preparedness aspect regarding the COVID19 pandemic is crucial. Such information can be a milestone to make concerned authorities aware of adverse consequences that may arise in case of obliviousness in managing their daily activities.

This study has been conducted to answer the following question: What are the perceptions and preparedness of international medical students residing in university hostels amid the COVID-19 pandemic lockdown in Pakistan?

To the best of our knowledge, this is the first of its kind study designed to evaluate the challenges faced by international medical students residing in university hostels amid COVID19 lockdown and their perceptions and preparedness towards it which might help the concerned authorities to prepare relevant public health strategies.

\section{METHODS}

\section{Ethical approval}

The ethics approval was received from the Institutional Ethics Review Board of the University of the Punjab, Lahore, Pakistan (Reference number:183/DFEMS). Informed verbal consent to participate in the study was obtained from participants.

\section{Study design}

A qualitative research methodology was adopted as it is flexible and focuses on non-numeric data that consent to an in-depth understanding of the respondent's perspective. Moreover, 
qualitative analysis supports identifying and fill in gaps that are left unnoticed by the quantitative types.

The COREQ (consolidated criteria for reporting qualitative research) checklist was utilized for reporting qualitative studies. ${ }^{12}$

\section{Instrument development}

A semi-structured interview guide was developed. It was tested for validity and reliability by two skilled researchers at the University of Veterinary and Animal Sciences, Lahore, Pakistan (B and E). It was pre-tested and verified for accuracy and consistency. The reliability of the findings was assured by recording face-to-face interviews with the international students following their approval.

\section{Respondents sampling and inclusion criteria}

The study was conducted in Punjab Province, which is the most developed, populated, and the second-largest province of Pakistan. The participants in the study were recruited using the purposive sampling technique based on their availability until saturation was achieved. A total of 11 international medical students residing in university hostels were finally selected for interview. The targeted participants were international students from various faculties of medicines such as pharmacy, veterinary, medical, and dental in universities around Punjab Province, Pakistan.

\section{In}

After giving an explanatory statement with the study objectives to the participants, verbal consent was taken. To ensure privacy, the identity of the respondents was kept confidential and 
the anonymity of opinions was also confirmed by using codes by the two researchers (SK and MU). Interviews were continued until the saturation point from where new data doesn't occur. The respondents were aware of voluntary involvement in the interview, and the independence to drop the participation at any time. The co-authors of the study interviewed the participants in their hostel room between April 2020 and June 2020 in the English language. All the interviews were audio-taped, and additional field notes were taken by the principal investigator SK (male). Suitable probing was done to seek out more information. The respondents were free to describe additional views on the topic. The duration of each interview was approximately 20-30 minutes.

\section{Analysis}

All the recorded interviews were transcribed verbatim. The comments were changed to some extent for grammatical corrections during the data extraction process. Based on the method described by Braun and Clarke, the data were thematically analyzed manually by in-depth penetration into the interviews. ${ }^{13}$ The significant answers were deductively highlighted. Then the answers were compared and contrasted to establish any variances and themes were identified by successively reorganizing the pattern. The transcribed interviews were analyzed for interconnected comments while categorizing the theme. This exercise helped cluster the statements that were previously considered unrelated or discrete. The interview was conducted in a very inductive and flexible manner to further explore the valid issues.

\section{RESULTS}

\section{Demographics of the participants}


A total of 11 participants from seven different Universities in Pakistan were included in the study $(n=11)$. The majority of them were from Universities located in Lahore $(n=8)$ followed by Multan $(n=2)$, and Faisalabad $(n=1)$. The participants belonged to six different countries of the Eastern Mediterranean Region (n=3), South-East Asia Region ( $\mathrm{n}=2)$, and African Region (n=1). There was a total of eight male students and the rest were female among the participants. The majority of the participants $(n=8)$ were of more than 25 years of age. Under-graduate students were nine in number followed by post-graduate level students. All the participants were staying in Pakistan for more than one year. The majority of the participants $(n=6)$ were from pharmacy faculty, three from medical, and one each from dentistry and veterinary faculties.

A flow diagram of the participants' recruitment is given in Figure 1. 


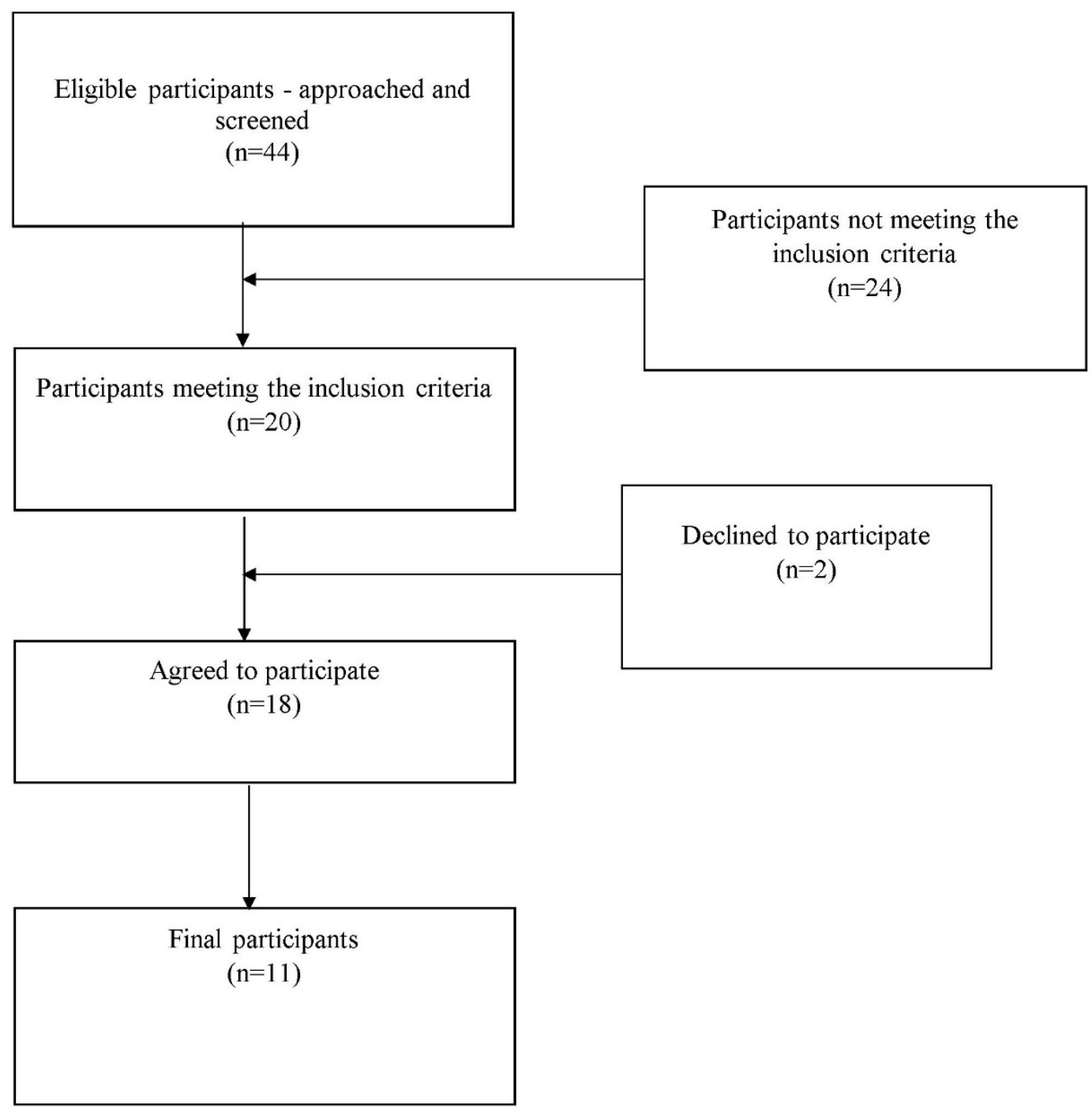

Figure 1 A flow diagram of the participants' recruitment for the qualitative interviews

The demographic distribution of the participants is described below in Table 1.

Table 1 Demographics of the participants

\begin{tabular}{|l|l|l|l|}
\hline Characteristics & Parameters & Frequency (n) & Percentage (\%) \\
\hline
\end{tabular}




\begin{tabular}{|c|c|c|c|}
\hline \multirow[t]{2}{*}{ Gender } & Male & 8 & 72.72 \\
\hline & Female & 3 & 27.27 \\
\hline \multirow[t]{2}{*}{ Age } & $<25$ years & 8 & 72.72 \\
\hline & $>25$ years & 3 & 27.27 \\
\hline \multirow[t]{2}{*}{ Education (Level) } & Under-graduate & 9 & 81.82 \\
\hline & Post-graduate & 2 & 18.18 \\
\hline \multirow{4}{*}{$\begin{array}{l}\text { Education } \\
\text { (Discipline) }\end{array}$} & Medicine & 3 & 27.27 \\
\hline & Pharmacy & 6 & 54.55 \\
\hline & Dentistry & 1 & 9.09 \\
\hline & Veterinary science & 1 & 9.09 \\
\hline \multirow[t]{2}{*}{ Stay duration } & $<1$ year & 0 & 0 \\
\hline & $>1$ year & 11 & 100 \\
\hline \multirow[t]{6}{*}{ Country of origin } & Nepal & 6 & 54.55 \\
\hline & Sri Lanka & 1 & 9.09 \\
\hline & Syria & 1 & 9.09 \\
\hline & Yemen & 1 & 9.09 \\
\hline & Iran & 1 & 9.09 \\
\hline & Kenya & 1 & 9.09 \\
\hline
\end{tabular}

\section{Thematic analysis of the content}

The thematic analysis of the content of the interview led to five major themes: 1. Familiarity with COVID-19 (Knowledge), 2. Perceptions and attitudes towards COVID-19 (Attitude), 3. 
medRxiv preprint doi: https://doi.org/10.1101/2021.08.02.21261480; this version posted August 5, 2021. The copyright holder for this preprint

(which was not certified by peer review) is the author/funder, who has granted medRxiv a license to display the preprint in perpetuity.

All rights reserved. No reuse allowed without permission.

Preparedness for safety against COVID-19 (Practice/Action), 4. Barriers to lifestyle (Experience/Outcome), and 5. Psychological perspectives (Experience/Outcome).

\section{Theme 1: Familiarity with COVID-19}

\section{Knowledge about COVID-19 pandemic - Overview}

The participants were interviewed regarding their knowledge about the COVID-19 pandemic. All of them answered in a similar way regarding the nature of the disease, origin, and causative agent, Table 2 .

\section{Knowledge about COVID-19 transmission}

The responses of all participants were almost similar regarding the modes of transmission, Table 2.

\section{Knowledge about COVID-19 management}

The majority of the participants had an appropriate concept about the therapy of COVID-19.

Some of the participants were a little bit confused regarding the name of the drugs used as a treatment option. However, many of them had an appropriate concept about ongoing trials for therapeutic and prophylactic agents and the use of only supportive therapy and the best possible option of treating agents available for COVID-19 management.

Therapy: The respondents' views are provided in table 2.

Prevention: Answering a query regarding social distancing, hand washing, using masks, gloves, and goggles as preventive measures; a majority of the respondents stated that these can only 
medRxiv preprint doi: https://doi.org/10.1101/2021.08.02.21261480; this version posted August 5, 2021. The copyright holder for this preprint (which was not certified by peer review) is the author/funder, who has granted medRxiv a license to display the preprint in perpetuity.

All rights reserved. No reuse allowed without permission.

lower the transmission rate but cannot prevent it at $100 \%$. Some of the participants believed that these measures help in the complete prevention of transmission of COVID-19. Different students expressed various views about the availability and survival of coronavirus in different mediums, Table 2.

Effectiveness of therapies: Though the majority of the students reported that the adopted treatment methods are only being used as the best possible option, some of them were not being able to express a clear answer regarding the effectiveness of the ongoing therapy, Table 2.

Table 2 Thematic analysis of the interview data and selected quotes of the respondents (Theme 1)

\begin{tabular}{|c|c|}
\hline $\begin{array}{l}\text { Theme } 1 \text { Familiarity with } \\
\text { COVID-19 } \\
\text { (Knowledge) } \\
\text { Subthemes }\end{array}$ & Selected quotes \\
\hline $\begin{array}{l}\text { 1.1 Knowledge about } \\
\text { COVID-19 pandemic - } \\
\text { Overview }\end{array}$ & $\begin{array}{l}\text { "Ok! COVID-19 pandemic basically is a viral disease that spreads very fast around } \\
\text { the globe. So, most of the symptoms of that are related to the respiratory system." } \\
\text { (IMS-4) } \\
\text { "COVID } 19 \text { pandemic is a new viral disease that originated in Wuhan, China, and it is } \\
\text { contagious in its spread and so far there is no cure, no foreseen, and no medication for } \\
\text { it." (IMS-10) }\end{array}$ \\
\hline $\begin{array}{l}\text { 1.2 Knowledge about } \\
\text { COVID-19 transmission }\end{array}$ & $\begin{array}{l}\text { "Ah! Ah! It transmits through the droplet infection and as it is an infectious disease of } \\
\text { the respiratory tract, it affects the respiratory system." (IMS-1) } \\
\text { "It gets transmitted when someone coughs, sneezes or speaks through small liquid } \\
\text { droplets from their nose or mouth which may contain a virus. So, it can be transmitted } \\
\text { to another person when he or she is closer than } 1 \text { meter, transmitted byways of } \\
\text { touching face or mouth by hands." (IMS-5) }\end{array}$ \\
\hline $\begin{array}{l}1.3 \text { Knowledge about COVID- } \\
19 \text { management }\end{array}$ & $\begin{array}{l}\text { 1.3.1 Therapy } \\
\text { "Ah! The research is going on, but until now the only supportive therapy is there, the } \\
\text { complete treatment has not been found yet." (IMS-1) } \\
\text { "Yes! Some of the drugs such as hydroxychloroquine and the drugs such as antiviral } \\
\text { drugs have also been used." (IMS-1) } \\
\text { "Until now there is no medications or vaccines that are approved by WHO but these } \\
\text { are under clinical trial, maybe like, chloroquine, hydroxychloroquine, and some } \\
\text { antiviral drugs." (IMS-9) } \\
\text { 1.3.2 Prevention } \\
\text { "I cannot say these can prevent 100\% of transmission but certainly lower the spread } \\
\text { transmission rate." (IMS-2) }\end{array}$ \\
\hline
\end{tabular}




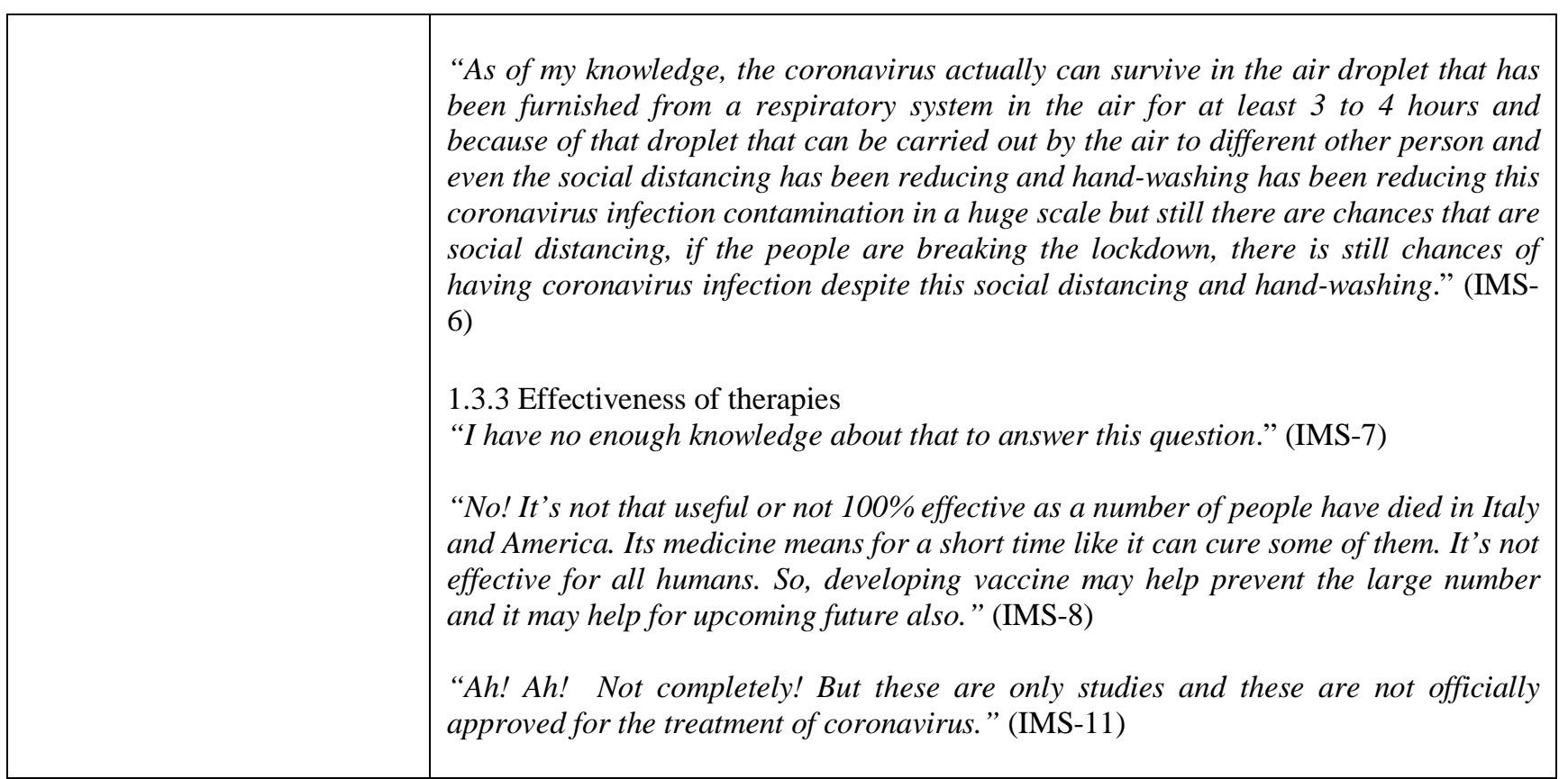

Abbreviations:- COVID-19: Coronavirus disease-2019, IMS 1-11: International medical student 1-11

\section{Theme 2: Perception and attitudes towards COVID-19}

\section{Risk of contracting COVID-19}

Regarding the risk of contracting COVID-19, all of the participants considered that they are at risk but some participants claimed that they are in a safer state than any other persons as they were confined in the hostels, Table 3.

\section{Community level-Lock down approach}

Regarding the lockdown approach as a containment strategy to prevent COVID-19, all the respondents showed a positive response, Table 3.

\section{Institutional level- University/hostel management}


medRxiv preprint doi: https://doi.org/10.1101/2021.08.02.21261480; this version posted August 5, 2021. The copyright holder for this preprint (which was not certified by peer review) is the author/funder, who has granted medRxiv a license to display the preprint in perpetuity.

All rights reserved. No reuse allowed without permission.

The mixed views were obtained upon asking for university and hostel management amid the COVID-19 pandemic. Some of the respondents even indicated dissatisfaction about the local scene as the people were not taking the lockdown seriously, Table 3.

\section{Personal level -Tackling aspect}

Upon a question related to tackling COVID-19 in case their fellow hostelers get infected with COVID-19, most of them asserted that they would suggest isolation and quarantine, while some of the respondents were intending to take them to hospital, while others did not state about isolation, quarantine, but discussed supportive therapy and other laboratory tests to conduct.

While replying to the query "What will you do if symptoms of flu that resemble COVID-19 occur?", the respondents emphasized on calling an emergency number, some of them were intending to get the test done and isolate themselves, while others said that they follow preventive measures to tackle such scenario, Table 3.

\section{Perception to rules and guidelines}

All of the respondents were found positive towards complying with the rules and guidelines set for the management of such a global health threat in an optimistic way, Table 3.

Table 3 Thematic analysis of the interview data and selected quotes of the respondents (Theme 2)

\begin{tabular}{|l|l|}
\hline $\begin{array}{l}\text { Theme 2 Perceptions and } \\
\text { attitudes towards COVID-19 } \\
\text { (Attitude) }\end{array}$ & Selected quotes \\
\hline Subthemes & \\
\hline
\end{tabular}


medRxiv preprint doi: https://doi.org/10.1101/2021.08.02.21261480; this version posted August 5, 2021. The copyright holder for this preprint

(which was not certified by peer review) is the author/funder, who has granted medRxiv a license to display the preprint in perpetuity.

All rights reserved. No reuse allowed without permission.

\begin{tabular}{|c|c|}
\hline $\begin{array}{l}\text { 2.1 Risk of contracting } \\
\text { COVID-19 }\end{array}$ & $\begin{array}{l}\text { "Especially we are in a hostel, if the sweeper or colleague or anyone inside the hostel, } \\
\text { they are affected, you know, by corona, is easily transmitted from them." (IMS-3) } \\
\text { "Yes! I think there is a possibility. Yes, there will be a possibility but any of the } \\
\text { students in the hostel get infected. So, I think, then we all will get infected but we are } \\
\text { safer than others outside the campus." (IMS-4) }\end{array}$ \\
\hline $\begin{array}{l}\text { 2.2 Community level-Lock } \\
\text { down approach }\end{array}$ & $\begin{array}{l}\text { "Lockdown is very important and effective for preventing a spread of COVID-19." } \\
\text { (IMS-5) } \\
\text { "Yes! It is an effective way to stay at home and it has, kind of, prevented spread like it } \\
\text { has broken spread of coronavirus, like, it's less infective. There was more possibility } \\
\text { that people may get suffer but due to lockdown, fewer people are suffering and we are } \\
\text { kind of safe." (IMS-8) }\end{array}$ \\
\hline $\begin{array}{l}2.3 \text { Institutional level- } \\
\text { University/hostel } \\
\text { management }\end{array}$ & $\begin{array}{l}\text { "I think this is not good at facilities." (IMS-11) } \\
\text { "Yes! Good! Right! Right!" (IMS-9) } \\
\text { "Ah! There are also precautionary measures and all the sanitary measures are } \\
\text { satisfactory but not 100\% perfect but our continuous effort is to warn the } \\
\text { administration for the better facilities provided here." (IMS-2) }\end{array}$ \\
\hline $\begin{array}{l}2.4 \text { Personal level- Tackling } \\
\text { aspects }\end{array}$ & $\begin{array}{l}\text { "Umm! If my hostel fellow gets affected by COVID-19, then he should go for isolation. } \\
\text { We must be staying in quarantine and, ah! Those we who are in contact with him } \\
\text { should stay in isolation too or might be quarantined." (IMS-1) } \\
\text { "Umm! First of all, I will call my hospital emergency and say about my conditions, } \\
\text { and say these are happening, and according to that situation they will tell me what to } \\
\text { do further." (IMS-1) } \\
\text { "I think, there are rules set even when one shows such kind of symptoms, he should } \\
\text { isolate himself, and of course, I will also have to take the precautionary measures like } \\
\text { not coming in touch with the infected." (IMS-10) } \\
\text { "Ok! What I will do is, I will report. You know there is a number I'm supposed to call } \\
\text { if I show such kind of symptoms. I will report and then, from there, I will take the } \\
\text { instruction they will give me" (IMS-10) }\end{array}$ \\
\hline $\begin{array}{l}2.5 \text { Perception to rules and } \\
\text { guidelines }\end{array}$ & $\begin{array}{l}\text { "Yes! I believe every individual is responsible for this condition, responsible for } \\
\text { following the necessary guidelines for the prevention of this disease. Because this is } \\
\text { not only yourself who is in danger, there is our family and the whole people of the } \\
\text { world are in danger. So, we must do whatever we are responsible for to protect } \\
\text { ourselves and the whole world." (IMS-11) } \\
\text { "Umm! Yes! I want to comment that let's hope for the best and let's follow the } \\
\text { guidelines that are provided by the local authorities and our government, and let's } \\
\text { stay strong. We will get through this." (IMS-1) }\end{array}$ \\
\hline
\end{tabular}

Abbreviations:- COVID-19: Coronavirus disease-2019, IMS 1-11: International medical student 1-11

\section{Theme 3: Preparedness for safety against COVID-19}


medRxiv preprint doi: https://doi.org/10.1101/2021.08.02.21261480; this version posted August 5, 2021. The copyright holder for this preprint (which was not certified by peer review) is the author/funder, who has granted medRxiv a license to display the preprint in perpetuity. All rights reserved. No reuse allowed without permission.

\section{Preventive measures}

Regarding preventive measures adopted against the COVID-19 pandemic, it was found that they carry hand sanitizer, wear masks and gloves, usually wash their hands with soap water, and follow social distancing as per guidelines, Table 4.

\section{Willingness to vaccination}

Regarding vaccination, mixed views were obtained, Table 4.

Table 4 Thematic analysis of the interview data and selected quotes of the respondents (Theme 3)

\begin{tabular}{|l|l|}
\hline $\begin{array}{l}\text { Theme } 3 \text { Preparedness for } \\
\text { safety against COVID-19 } \\
\text { (Practice/Action) }\end{array}$ & \multicolumn{1}{|c|}{ Selected quotes } \\
\hline Subthemes & $\begin{array}{l}\text { "Hand sanitizing, wearing a mask, and social distancing."( IMS-7) } \\
\text { "Ok! The first measure is that you should be staying home until and unless you have } \\
\text { urgent work, and the second thing is that if you have urgent and fundamental and most } \\
\text { necessary things that you have to go to the outside, then only one individual should go. } \\
\text { And if it is possible, then going outside should be completely with the protective } \\
\text { measures like using the mask. Mask is compulsory." (IMS-6) } \\
\text { "Yes! I am somehow prepared to Ah! Ah! Prevent from this disease." (IMS-5) } \\
\text { "Probably Yes! Because I usually try to stay in lockdown and wash my hand } \\
\text { frequently and sanitize surfaces." (IMS-11) }\end{array}$ \\
\hline $\begin{array}{l}3.2 \text { Willingness to } \\
\text { vaccination }\end{array}$ & $\begin{array}{l}\text { "Yes! I will." (IMS-10) } \\
\text { "Yes! If it's available, I will. Everybody wants to take a vaccine." (IMS-3) } \\
\text { "I am not 100\% willing to get vaccinated. I think so, but let's see." (IMS-4) }\end{array}$ \\
\hline
\end{tabular}

Abbreviations:- COVID-19: Coronavirus disease-2019, IMS 1-11: International medical student 1-11

\section{Theme 4: Barriers to the lifestyle}


medRxiv preprint doi: https://doi.org/10.1101/2021.08.02.21261480; this version posted August 5, 2021. The copyright holder for this preprint (which was not certified by peer review) is the author/funder, who has granted medRxiv a license to display the preprint in perpetuity.

All rights reserved. No reuse allowed without permission.

The lockdown approach and social distancing adopted as a containment strategy were considered barriers to the everyday lifestyle during the COVID-19 pandemic. They were not shaking hands, hugging friends, sharing stuff such as phones and utensils, and touching any surfaces outside the room which they felt unusual, though following these as a guideline, Table 5.

\section{Impact of movement restriction}

Not getting an opportunity for conventional classes, not going out from the hostel frequently, not being able to go home, and being confined within the hostel premises were among the responses obtained, Table 5.

\section{Effect on daily activities}

The majority of the respondents replied that changes in routine which disturbed timing to go for internship, physical activities, and meal timing were the most affected daily activities by the COVID-19 pandemic, Table 5.

Lifestyle dropped due to COVID-19: Regarding lifestyle changes due to the COVID-19 pandemic, the responses are depicted in Table 5.

Lifestyle adopted due to COVID-19: Pastime activities of most of the respondents during the COVID-19 pandemic were reading books including course books and news articles, playing games, and using social media, Table 5.

Table 5 Thematic analysis of the interview data and selected quotes of the respondents (Theme 4) 
medRxiv preprint doi: https://doi.org/10.1101/2021.08.02.21261480; this version posted August 5, 2021. The copyright holder for this preprint (which was not certified by peer review) is the author/funder, who has granted medRxiv a license to display the preprint in perpetuity.

All rights reserved. No reuse allowed without permission.

\begin{tabular}{|c|c|}
\hline (Experience/Outcome) & \\
\hline Subthemes & \\
\hline $\begin{array}{l}4.1 \text { Impact of movement } \\
\text { restriction }\end{array}$ & $\begin{array}{l}\text { "Yes! Mainly my education system is changed. I am studying online." (IMS-7) } \\
\text { "Yes! I was going back home but couldn't because of a virus.” (IMS-9) } \\
\text { "I only go to buy necessary things, like, once in a week or twice maybe, sometimes to } \\
\text { buy goods; the necessary goods, the food that is necessary.” (IMS-8) }\end{array}$ \\
\hline 4.2 Effect on daily activities & $\begin{array}{l}\text { "Ah! We used to go to the hospital. We used to do our job like } 5 \text { to } 6 \text { hours a day, but } \\
\text { now we are going only } 1 \text { day per week, and ah! I also cannot go outside and we used } \\
\text { to go outside for exercise. Ah! And it has also affected differently - our food, our way } \\
\text { of eating, way of sleeping, everything is affected." (IMS-1) } \\
\text { "Yes! Because it reduces the daily physical activities and forces us to do our work } \\
\text { almost at home." (IMS-11) } \\
4.2 .1 \text { Lifestyle dropped due to COVID-19 } \\
\text { "Ah! Yes! It changes lifestyle because we have to stay at a hostel and we can't do daily } \\
\text { activities like as usual." (IMS -5) } \\
\text { "Yes! Definitely! For example, I don't get to hug my friends. I don't get to shake } \\
\text { hands. I don't get to go out as I used to do before when my studies, my studies are } \\
\text { disrupted. So, completely it has changed my life." (IMS-10) } \\
\text { "Y.2.2 Lifestyle adopted due to COVID-19 } \\
\text { "I am just watching umm! YouTube videos, doing stuff and sometimes read books, and } \\
\text { sometimes I see my phone like that." (IMS-1) } \\
\text { "Currently, I am mostly using social media. Then in free time like you can say, after } \\
\text { getting bored from social media, I read a book." (IMS-2) } \\
\end{array}$ \\
\hline
\end{tabular}

Abbreviations:- COVID-19: Coronavirus disease-2019, IMS 1-11: International medical student 1-11

\section{Theme 5: Psychological perspectives}

\section{Fear of COVID-19}

There were mixed reactions regarding fear of COVID-19 such as some were scared, while others were cautious rather than being scared, Table 6.

Contraction: The responses are depicted in Table 6. 
medRxiv preprint doi: https://doi.org/10.1101/2021.08.02.21261480; this version posted August 5, 2021. The copyright holder for this preprint (which was not certified by peer review) is the author/funder, who has granted medRxiv a license to display the preprint in perpetuity.

All rights reserved. No reuse allowed without permission.

Death: Though the respondents were scared of being infected, they did not have fear of death, Table 6.

Isolation: The mixed views were obtained regarding isolation, Table 6.

Effect on career or studies: Though the respondents indicated interruption of regular classes, they were managing time for study in the hostel room and some of them had even started scientific writing, Table 6.

\section{Self-esteem}

Upon a question related to lowering of self-esteem due to either COVID-19 pandemic or due to lock down or both, mixed reactions were obtained. Some of the respondents stated both as a reason for lowering self-esteem. However, the majority of the respondents reported no lowering at all in their self-esteem as those approaches were adopted for a good reason, Table 6.

\section{Loneliness}

The majority of the respondents were missing their family members back home, while some were frustrated and facing difficulties, Table 6.

\section{Stress}

The respondents were found in stress as they were far from family members, staying inside the hostel room for so long, and their minds were filled with the uncertainty of disease progression, Table 6.

Table 6 Thematic analysis of the interview data and selected quotes of the respondents (Theme 5) 
medRxiv preprint doi: https://doi.org/10.1101/2021.08.02.21261480; this version posted August 5, 2021. The copyright holder for this preprint (which was not certified by peer review) is the author/funder, who has granted medRxiv a license to display the preprint in perpetuity.

All rights reserved. No reuse allowed without permission.

\begin{tabular}{|c|c|}
\hline $\begin{array}{l}\text { perspectives } \\
\text { (Experience/Outcome) }\end{array}$ & \\
\hline 5.1 Fear of COVID-19 & $\begin{array}{l}\text { 5.1.1 Contraction } \\
\text { "Yes! I am scared a little bit." (IMS-3) } \\
\text { "Umm! I am not scared! And if we take precaution, there is no way of transmission of } \\
\text { this disease." (IMS-5) } \\
\text { "I am not that kind of scared but there is a risk, so you must be precautious." (IMS-2) } \\
\text { 5.1.2 Death } \\
\text { It's not that deadly. Its mortality rate is only 2\% and 98\% of people get recoveries } \\
\text { from it. (IMS-8) } \\
\text { "I.1.3 Isolation } \\
\text { "It's not enjoyable. It's difficult." (IMS-7) } \\
\text { "I guess, it is good because no one enters in hostel, campus." (IMS-9) } \\
\text { After the coronavirus pandemic, I have been isolated in my room and even my regular } \\
\text { daily activities have been changed drastically like I'm not able to go outside that much } \\
\text { and even to my college and hospital everywhere that I used to attend previously in the } \\
\text { normal days, that has been hampered in my life. (IMS-6) } \\
\text { "Ohaking my article. I have 20 articles in my room." (IMS-9) }\end{array}$ \\
\hline 5.2 Self-esteem & $\begin{array}{l}\text { "Yea! Due to both." (IMS-1) } \\
\text { "Ah! No! My self-esteem is not low because I do believe that we have a responsibility } \\
\text { for yourselves and society to follow lockdown and carefully follow self-hygiene. If we } \\
\text { care about our responsibilities then there are no worries; whether we get infected or } \\
\text { not. Because if even we get infected, we know that had tried to follow the guidelines } \\
\text { and responsibilities well." (IMS-11) } \\
\text { "No! Like in the early days, it was kind of enjoyable like we were getting holidays } \\
\text { from university. It was relaxing eating but nowadays, as the days are increasing, it's } \\
\text { like more loneliness or something like that. We are more alone. We are bored by doing } \\
\text { the same thing daily. So, kind of someday sometimes we get frustrated. We are given a } \\
\text { single room, so it's not enjoyable." (IMS-8) }\end{array}$ \\
\hline 5.3 Loneliness & $\begin{array}{l}\text { "Yes! I am missing them. I miss them so badly that I cried some days like I can't say } \\
\text { but the condition is so worse that I can't even go." (IMS-8) } \\
\text { "Certainly! I am missing my family." (IMS-2) }\end{array}$ \\
\hline 5.4 Stress & $\begin{array}{l}\text { "Yes! Lots of changes. It's mentally challenging." (IMS-1) } \\
\text { "I have never stayed in the room for } 2 \text { months as we are right now so I am getting too }\end{array}$ \\
\hline
\end{tabular}


medRxiv preprint doi: https://doi.org/10.1101/2021.08.02.21261480; this version posted August 5, 2021. The copyright holder for this preprint (which was not certified by peer review) is the author/funder, who has granted medRxiv a license to display the preprint in perpetuity.

All rights reserved. No reuse allowed without permission.

\begin{tabular}{|l|l|}
\hline & $\begin{array}{l}\text { much bored." (IMS-4) } \\
\text { "Yes! I am sort of yea, I am like, I am scared that what will happen. I am in Pakistan, I } \\
\text { am not with my family members." (IMS-8) }\end{array}$ \\
\hline
\end{tabular}

Abbreviations:- COVID-19: Coronavirus disease-2019, IMS 1-11: International medical student 1-11

\section{DISCUSSION}

The outcome of this study has portrayed the typical picture of international medical students amid the COVID-19 pandemic from several aspects such as; knowledge about COVID-19, perceptions and attitudes towards it, and preparedness and safety against it.

The present study reported that the international medical students had adequate knowledge about the origin, causative agent, nature, and treatment strategy of COVID-19. However, some of them had less information about its treating agents and vulnerability issues. Our findings are in line with the findings of studies conducted in different parts of the world. ${ }^{14-17}$ Whereas the findings from a study conducted in Turkey were somewhat in different line where the knowledge of the medical students was found moderate. ${ }^{18}$ The audio-visual demonstrations, online webinars, and regular capacity development activities help improve the knowledge and skill in such pandemics. COVID-19 pandemic has worryingly endangered the existence of people around the globe. The unavailability of proven therapeutic agents and lockdown and social distancing adopted as preventive measures to contain such pandemic has disturbed the normal pattern of life everywhere. ${ }^{19,20}$

It was identified that the preventive measures were adopted at an adequate level by all the international students. Social distancing, hand washing with soap and water or using sanitizer, wearing masks and gloves, maintaining social distancing, limiting movements, changing and washing clothes frequently, and taking showers were the most frequently adopted preventive measures to avoid infection. Different studies have demonstrated the effectiveness of preventive 
measures as an appropriate strategy to limit the spread of coronavirus. ${ }^{6,21}$ Similar preventive measures were adopted by medical students in a study conducted by Khasawneh et al in Jordan. ${ }^{16}$ Whereas medical students were least compliant towards the adoption of such preventive approaches in a study conducted by Haque et al. ${ }^{22}$ Preventive measures are, no doubt, helpful due to the unavailability of approved therapeutic agents. But, the regular testing of COVID-19 in mass, effective contact tracing, increasing number of hospital beds, capacity of intensive care units (ICU), ventilators, and effective facility of quarantine and isolations are need of an hour. ${ }^{23}$ Preventive measures coupled with strengthening medical infrastructure throughout the country help ineffective containment of such pandemics.

The finding of the perception of risk of getting infected with COVID-19 indicates the requirement of the counseling sessions and stringent preventive measures. Though the respondents considered themselves safer than other people outside the periphery, most of them felt the risk of transmission from the attendants and other fellow hostelers. Willingness to stay in quarantine or in isolation in case of being exposed to or infected with COVID-19 exhibits a positive attitude. Our findings contrast with the results of a study conducted in Jordan where $4.2 \%$ of students were intended to escape isolation in case they were tested COVID-19 positive. ${ }^{16}$ Whereas the outcome of our study is in line with the study conducted by Maheshwari et al in India which demonstrated a positive attitude and appropriate practice in the majority of the participants.

The present study also demonstrates the social nature of students such as; willingness to help society with the COVID-19 pandemic and support friends in case of getting infected. Such an attitude depicts peace of mind. However, the concept of "first me" expressed in some cases might be attributed to the adverse scenario and mental stress caused by such pandemic. 
The respondents of the study believe that lockdown is the proper approach for the management of such pandemics. Contrary to this, different studies suggest that the theoretical research used for implementing the lockdown approach was farther than the practical aspect which had neglected the associated psychological effects. ${ }^{24,25}$ Altman $M$ describes lockdown as a misapplied and sub-optimal policy as it has disturbed the world's economy and emphasizes on the inclusion of more comprehensive governance and improvised mental models as crucial factors for human welfare in such measures. ${ }^{24}$ A study conducted by Zheng et al reported that the lockdown approaches contributed a buffer effect on social anxiety and the mediating effect on psychological distancing. ${ }^{25}$

The eagerness of international students to get vaccinated, as soon as it is available, implies their willingness to be stress-free of the pandemic and trust towards the immediate development of scientific research. However, at the same time, some of them were in a wait-and-see mood for the same. A similar type of result was reported by various studies where the majority of the people were willing but some were either unwilling or uncertain to get vaccinated. ${ }^{26-29}$ The reluctant respondents in the studies were mostly from ethnic minorities and had lower levels of education and income. ${ }^{26,29}$ Different reports suggest that the mistrust towards vaccines and fear of future side effects are responsible for people's reluctance towards getting a vaccination. ${ }^{26,30,31}$ Doubt in the current treatment strategy being adopted as a therapeutic option is creating fear among students. Such poor compliance urges for an immediate policy response tailored to public health awareness programs. ${ }^{26}$

The present study identified mixed responses from international students about the university and hostel management towards their welfare amid the COVID-19 pandemic. The majority of the respondents reported a satisfactory response, however, some of them were found a little bit 
dissatisfied with the authority. The respondents said that their normal routine has been disturbed due to the university shut down, restriction in movement, and confinement within the hostel periphery. In addition to this lack of physical activity, mess closure, the uncertainty of the situation make them miss their family more which may lead to psychosocial stress. Opening of mess for international students, proper hygiene and sanitation measures, virtual teaching-learning process, and online awareness training and webinar regarding the containment aspect of disease to protect themselves and to the society is required. School closure and loss in their learning are some of the prime concerns raised by the respondents. Lockdown has affected the global education system. The education system in LMICs was already facing many challenges, COVID19 adds more stress to it. This establishes the urgent need for multimodal approaches for achieving the course content objectives enabling learners in analytical reasoning to deal with the complexity of online education. ${ }^{32}$ Timely and significant teaching-learning techniques must be implemented for medical students as it is mandatory to have a significant understanding and education that enhances performances in such pandemics for the safety of the country. ${ }^{18}$

The study reports the compliance of respondents with the COVID-19 containment strategies of the government. The safety and security concerns, opening groceries for international students for a limited time, medical facilities, as well as regular and authentic sharing of COVID-19 information through newspapers, are praiseworthy steps taken government. The majority of respondents' intact self-esteem even at a bit frustrating scenario like this implies their intact mental status as well as good governance.

Multiple stressors may contribute to psychological stress and anxiety such as the perceived risk of infection, reduced social communications, and augmented worries on academic performance. ${ }^{33}$ The study also depicts the same. Most of the respondents had fear of getting 
contracted and impact in study and career but nobody had any fear of death as the mortality rate of COVID-19 is very low as compared to many other common diseases. ${ }^{34}$ A study conducted by Saddik et al reported higher anxiety levels in medical students during clinical rotation that decreased with online learning. ${ }^{15}$ Crisis like the COVID-19 pandemic gives substantial psychosocial burdens on humankind. Therefore, developing interventions and preventive strategies are crucial to address the psychological impact on international students due to such a pandemic. ${ }^{33}$ The focus must be given towards solidarity and social justice to deal with social stigma as well, which may occur at any point amid such pandemic and, if go unchecked, may lead to the mental disorder. ${ }^{35}$ A proper health communication is an urgent requirement as per WHO's the current report for the quality of life both from the health and social point of view. ${ }^{36}$ Cohesiveness and solidarity are effective coping mechanisms for stress and anxiety. ${ }^{33}$

Therefore, there is a need for an immediate action plan, supported by behavioral and social sciences, for alleviating the possibly overwhelming impacts of such pandemics to help align human behavior. ${ }^{36}$

This study depicts the compliance of international students with the guidelines for effective management of the COVID-19 pandemic. The finding of the study aligns with the study by Saddik et al where medical students were found to be utilizing reliable sources of information for COVID-19 management. ${ }^{15}$ Such adherence is critical for the effective management of such a global health threat. Lifestyle adopted for well-being amid such a pandemic by international students were timely and productive as well. Many of them were engaged in scientific publications which was a quality fruitful way to live for medical students.

\section{Strengths and limitations}


medRxiv preprint doi: https://doi.org/10.1101/2021.08.02.21261480; this version posted August 5, 2021. The copyright holder for this preprint (which was not certified by peer review) is the author/funder, who has granted medRxiv a license to display the preprint in perpetuity.

All rights reserved. No reuse allowed without permission.

This study is novel as it is the first of its kind study. It has delivered a convenient and comprehensive understanding of the knowledge, perception, and preparedness of the international medical students residing in hostels of different Universities of Pakistan towards the COVID-19 pandemic. A significant strength of this study was the inclusion of international students of six countries who are pursuing medical courses in seven Universities in different places of Pakistan. This enabled an in-depth exploration of the range of knowledge, perceptions, and preparedness as well of such students towards the COVID-19 pandemic. This study informs about the status of international medical students in Pakistan that can help their management with a quality stay in such a global pandemic. In this context, this study can have an impact in filling the prevailing gap in the qualitative, academic, and administrative issues between the international medical students and the respective authority and the literature as well. All the participants were guaranteed the secrecy and confidentiality of their profile, and the interview was also taken by international students in Pakistan. Therefore, the participants liberally and decently communicated their feelings. Besides, the data analysis based on a thematic analysis method simplified the generation of typical findings.

Moreover, there are some probable limitations linked to this qualitative study. This study was carried out only in the universities located in the Punjab province, Pakistan. Therefore, the findings of this study may not be generalized to the whole country, but the findings in other provinces may not vary with our findings.

\section{CONCLUSION}

The study furnishes important information on the perception and preparedness of international medical students regarding the COVID-19 pandemic. Respondents believed that maintaining 
personal hygiene using masks, gloves, and sanitizers and frequent hand-washing; maintaining social distancing; and complying with lockdown measures aid in COVID-19 management. The majority of them had a clear understanding of the COVID-19 pandemic. The support from the universities is the primary requirement for international students to cope with such pandemic as there is no approved therapy and preventive measures cannot always be adequate to sufficiently thwart COVID-19. Furthermore, the chance of psychological stress is high that could substantially harm their quality of life. The findings from the present study demand timely and evidence-based teaching-learning techniques for medical students as it is mandatory to have a significant understanding that enhances performances in such pandemics for global safety. Such a technique could ensure their mental health and make them self-motivated. In such a situation, the students prefer to use their time productively and this could have a long-term effect on their careers and academic progress. The respondents' perspectives from the present study help government to prepare relevant public health strategies based on population-focused approaches for effective management of such a disaster.

Author contributions Conceptualisation: SK, MU. Methodology: SK, MU, RPG, YB, and JS. Formal analysis: SK, MU, MS, HR, and MA. Writing-original draft: SK, SG, and MU. Writingreview and editing: MS, HR, SG, and HAS. Approval of final manuscript: all authors.

Special acknowledgment We are highly grateful to Mr. Tank Prasad Yadav and Mr. Pallav Aryal for their support in the finalization of this manuscript. 
medRxiv preprint doi: https://doi.org/10.1101/2021.08.02.21261480; this version posted August 5, 2021. The copyright holder for this preprint (which was not certified by peer review) is the author/funder, who has granted medRxiv a license to display the preprint in perpetuity.

All rights reserved. No reuse allowed without permission.

Funding support We declare that we have not received any specific grant for this research from any funding agency in the public, commercial or not-for-profit sectors.

Declaration of interests We declare that we have no conflict of interest.

Ethical approval The ethics approval was received from the Institutional Ethics Review Board of the University of the Punjab, Lahore, Pakistan (Reference number: 183/DFEMS). Informed verbal consent to participate in the study was obtained from participants.

\section{ORCID iD}

Sitaram Khadka https://orcid.org/0000-0002-0251-3817

Muhammad Usman https://orcid.org/0000-0003-4854-1888

Mohammad Saleem https://orcid.org/0000-0001-5064-1584

Moshin Ali https://orcid.org/0000-0002-3427-7855

Huma Rasheed https://orcid.org/0000-0002-5541-8856

Ravi Prasad Gupta https://orcid.org/0000-0002-6775-1672

Yogesh Bajgain https://orcid.org/0000-0002-3834-9684

Janak Shahi https://orcid.org/0000-0002-1598-8053 


\section{REFERENCES}

1. Giri S, Khadka S, Ranabhat S, Agha M. Gender Issue in COVID-19 Pandemic. J Karnali Acad Heal Sci. 2020;3(2):152-8.

2. Coronavirus (COVID-19) [Internet]. WHO. 2020 [cited 2021 Mar 6]. Available from: https://who.sprinklr.com/

3. WHO. COVID-19 Vaccines [Internet]. WHO. 2021 [cited 2021 Jul 30]. Available from: https://www.who.int/emergencies/diseases/novel-coronavirus-2019/covid-19vaccines/advice

4. Hegarty S. Covid vaccine tracker: How's my country and the rest of the world doing? BBC News [Internet]. 2021 [cited 2021 Jul 30]; Available from: https://www.bbc.com/news/world-56025355

5. Khadka S, Yuchi A, Shrestha D, Budhathoki P, Al-Subari S, Alhouzani T, et al. Repurposing Drugs for COVID-19: An Approach for Treatment in the Pandemic. Altern Ther Health Med. 2020;AT6513.

6. Khadka S, Hashmi FK, Usman M. Preventing COVID-19 in low- and middle-income countries. Drugs Ther Perspect. 2020;

7. Firang D. The impact of COVID-19 pandemic on international students in Canada. Int Soc Work [Internet]. 2020;63(6):820-4. Available from: https://doi.org/10.1177/0020872820940030

8. Children at increased risk of harm online during global COVID-19 pandemic - UNICEF [Internet]. Unicef. 2020. Available from: https://www.unicef.org/southafrica/pressreleases/children-increased-risk-harm-online-during-global-covid-19-pandemic-unicef

9. COVID-19: The countries reporting the highest mental health declines [Internet]. World 
Economic Forum. 2020 [cited 2021 Jan 7]. Available from:

https://www.weforum.org/agenda/2020/08/covid-19-coronavirus-mental-health-wellbeing-countries/

10. Sher L. The impact of the COVID-19 pandemic on suicide rates. QJM An Int J Med [Internet]. 2020; Available from: https://doi.org/10.1093/qjmed/hcaa202

11. Brådvik L. Suicide Risk and Mental Disorders. Vol. 15, International journal of environmental research and public health. 2018.

12. Tong A, Sainsbury P, Craig J. Consolidated criteria for reporting qualitative research (COREQ): a 32-item checklist for interviews and focus groups. Int J Qual Heal Care [Internet]. 2007;19(6):349-57. Available from: https://doi.org/10.1093/intqhc/mzm042

13. Braun V, Clarke V, Hayfield N, Terry G. Thematic Analysis. In: Liamputtong P, editor. Handbook of Research Methods in Health Social Sciences [Internet]. Singapore: Springer Singapore; 2019. p. 843-60. Available from: https://doi.org/10.1007/978-981-10-52514_103

14. Peng Y, Pei C, Zheng Y, Wang J, Zhang K, Zheng Z et al. A cross-sectional survey of knowledge, attitude and practice associated with COVID-19 among undergraduate students in China. BMC Public Health. 2020;20(1).

15. Saddik B, Hussein A, Sharif-Askari FS, Kheder W, Temsah M-H, Koutaich RA, et al. Increased Levels of Anxiety Among Medical and Non-Medical University Students During the COVID-19 Pandemic in the United Arab Emirates. Risk Manag Healthc Policy. 2020;13:2395-406.

16. Khasawneh AI, Humeidan AA, Alsulaiman JW, Bloukh S, Ramadan M, Al-Shatanawi TN, et al. Medical Students and COVID-19: Knowledge, Attitudes, and Precautionary 
Measures. A Descriptive Study From Jordan. Front public Heal. 2020;8:253.

17. Maheshwari S, Gupta P, Sinha R, Rawat P. Knowledge, attitude, and practice towards coronavirus disease 2019 (COVID-19) among medical students: a cross-sectional study. J Acute Dis. 2020;9(3):100-4.

18. Çalışkan F, Mıdık Ö, Baykan Z, Şenol Y, Tanrıverdi EÇ, Tengiz Fİ, et al. The knowledge level and perceptions toward COVID-19 among Turkish final year medical students. Postgrad Med [Internet]. 2020;132(8):764-72. Available from: https://doi.org/10.1080/00325481.2020.1795486

19. Khadka S, Nisar S, Syed N-I-H, Shrestha DB, Budhathoki P. Different aspects of convalescent plasma therapy for COVID-19 treatment; a critical review. Immunopharmacol Immunotoxicol. 2021 Feb;43(1):30-6.

20. Jiloha R. COVID-19 and Mental Health. Epidem Int. 2020;5(1):7-9.

21. Pradhan D, Biswasroy P, Kumar Naik P, Ghosh G, Rath G. A Review of Current Interventions for COVID-19 Prevention. Arch Med Res. 2020 Jul;51(5):363-74.

22. Haque A, Mumtaz S, Khattak O, Mumtaz R, Ahmed A. Comparing the preventive behavior of medical students and physicians in the era of COVID-19: Novel medical problems demand novel curricular interventions. Biochem Mol Biol Educ a Bimon Publ Int Union Biochem Mol Biol. 2020 Sep;48(5):473-81.

23. Lahiri A, Jha SS, Bhattacharya S, Ray S, Chakraborty A. Effectiveness of preventive measures against COVID-19: A systematic review of In Silico modeling studies in indian context. Indian J Public Health. 2020 Jun;64(Supplement):S156-67.

24. Altman M. Smart thinking, lockdown and Covid-19: Implications for public policy. J Behav Econ Policy. 2020;4(COVID-19 Special Issue):23-33. 
medRxiv preprint doi: https://doi.org/10.1101/2021.08.02.21261480; this version posted August 5, 2021. The copyright holder for this preprint

(which was not certified by peer review) is the author/funder, who has granted medRxiv a license to display the preprint in perpetuity.

All rights reserved. No reuse allowed without permission.

25. Zheng L, Miao M, Lim J, Li M, Nie S, Zhang X. Is Lockdown Bad for Social Anxiety in COVID-19 Regions?: A National Study in The SOR Perspective. Int J Environ Res

Public Health. 2020 Jun; 17(12).

26. Paul E, Steptoe A, Fancourt D. Attitudes towards vaccines and intention to vaccinate against COVID-19: Implications for public health communications. Lancet Reg Heal - Eur [Internet]. 2020;100012. Available from:

http://www.sciencedirect.com/science/article/pii/S2666776220300120

27. Yoda T, Katsuyama H. Willingness to Receive COVID-19 Vaccination in Japan. Vaccines [Internet]. 2021;9(1). Available from: https://www.mdpi.com/2076-393X/9/1/48

28. Neumann-Böhme S, Varghese NE, Sabat I, Barros PP, Brouwer W, van Exel J, et al. Once we have it, will we use it? A European survey on willingness to be vaccinated against COVID-19. Vol. 21, The European journal of health economics $\square$ : HEPAC $\square$ : health economics in prevention and care. 2020. p. 977-82.

29. Dodd RH, Cvejic E, Bonner C, Pickles K, McCaffery KJ, Sydney Health Literacy Lab COVID-19 group. Willingness to vaccinate against COVID-19 in Australia. Lancet Infect Dis [Internet]. 2020 Jun; Available from: https://europepmc.org/articles/PMC7326391

30. The Associated Press and NORC. Expectations for a COVID-19 vaccine. [Internet]. 2020 [cited 2020 Jan 26]. Available from: https://apnorc.org/projects/expectations-for-a-covid19-vaccine/

31. The Lancet. Infectious diseases. A future vaccination campaign against COVID-19 at risk of vaccine hesitancy and politicisation. $2020 \mathrm{Jul} ; 20(7): 769-70$.

32. Mishra L, Gupta T, Shree A. Online teaching-learning in higher education during lockdown period of COVID-19 pandemic. Int J Educ Res Open [Internet]. 2020;1:100012. 
medRxiv preprint doi: https://doi.org/10.1101/2021.08.02.21261480; this version posted August 5, 2021. The copyright holder for this preprint

(which was not certified by peer review) is the author/funder, who has granted medRxiv a license to display the preprint in perpetuity.

All rights reserved. No reuse allowed without permission.

Available from: http://www.sciencedirect.com/science/article/pii/S2666374020300121

33. Son C, Hegde S, Smith A, Wang X, Sasangohar F. Effects of COVID-19 on College

Students' Mental Health in the United States: Interview Survey Study. J Med Internet

Res. 2020 Sep;22(9):e21279.

34. Younis I, Longsheng C, Zulfiqar MI, Imran M, Shah SAA, Hussain M, et al. Regional disparities in Preventive measures of COVID-19 pandemic in China. A study from international students' prior knowledge, perception and vulnerabilities. Environmental science and pollution research international. 2020. p. 1-16.

35. Bhattacharya P, Banerjee D, Rao TS. The "Untold" Side of COVID-19: Social Stigma and Its Consequences in India. Indian J Psychol Med. 2020 Jul;42(4):382-6.

36. Bavel JJ Van, Baicker K, Boggio PS, Capraro V, Cichocka A, Cikara M, et al. Using social and behavioural science to support COVID-19 pandemic response. Nat Hum Behav. 2020 May;4(5):460-71. 


\section{Tables/Figure Legends}

Table 1 Demographics of the participants

Table 2 Thematic analysis of the interview data and selected quotes of the respondents (Theme 1)

Table 3 Thematic analysis of the interview data and selected quotes of the respondents (Theme 2)

Table 4 Thematic analysis of the interview data and selected quotes of the respondents (Theme 3)

Table 5 Thematic analysis of the interview data and selected quotes of the respondents (Theme 4)

Table 6 Thematic analysis of the interview data and selected quotes of the respondents (Theme 5)

Figure 1 A flow diagram of the participants' recruitment for the qualitative interviews 


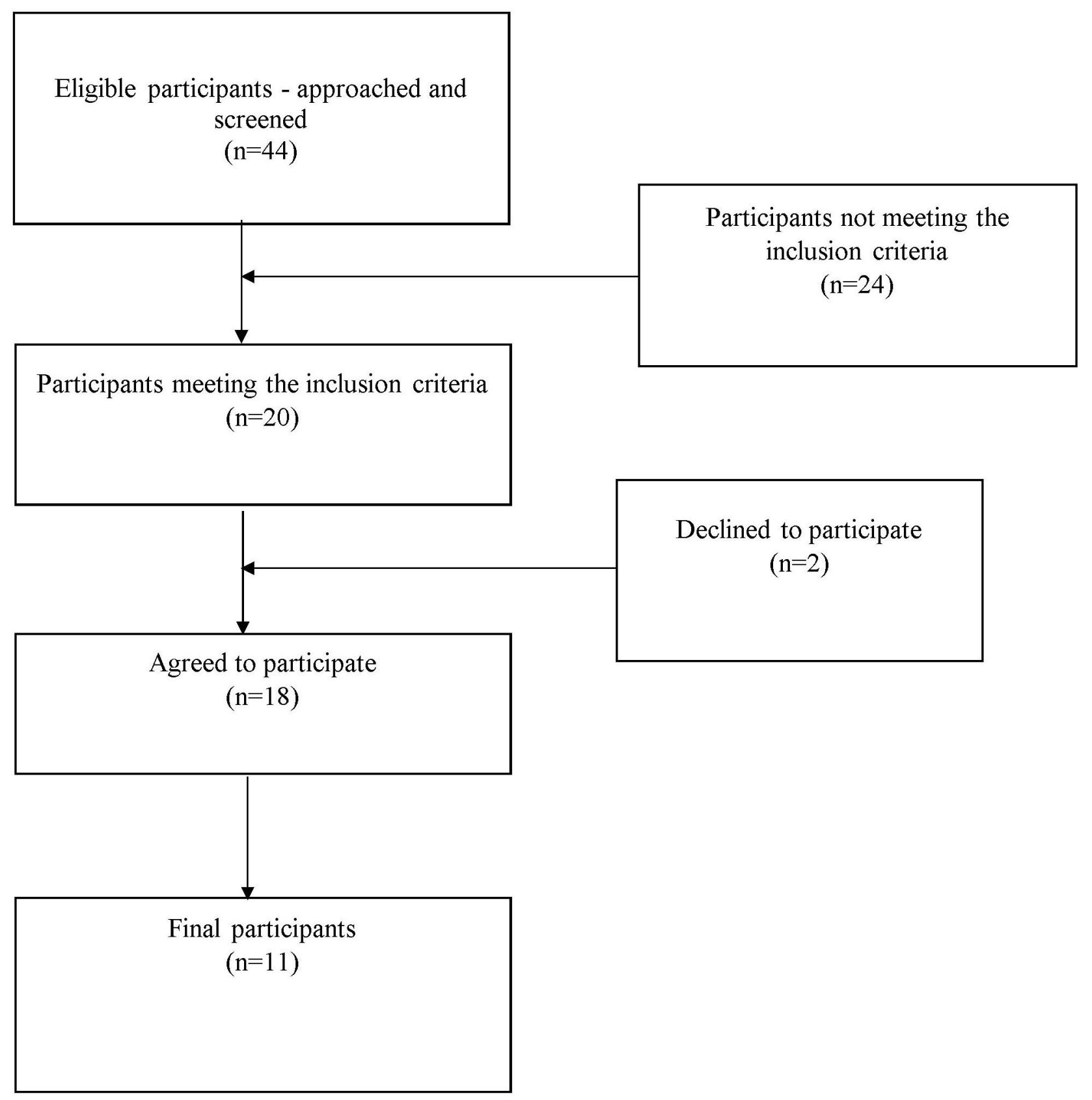

